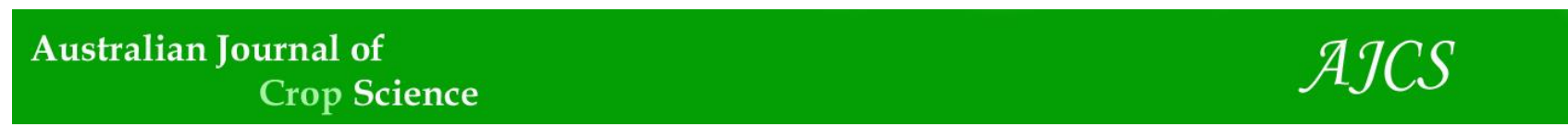

AJCS 12(10):1573-1577 (2018)

ISSN:1835-2707

doi: 10.21475/ajcs.18.12.10.p1114

\title{
Agronomic performance and economic profitability of lettuce fertilized with Calotropis procera as a green manure in a single crop
}

\author{
Italo Nunes Silva, Francisco Bezerra Neto, Aurélio Paes Barros Júnior*, Jailma Suerda Silva de Lima, \\ Aridênia Peixoto Chaves, José Ricardo Tavares de Albuquerque, Hamurábi Anizio Lins, Manoel Galdino \\ dos Santos, Enielson Bezerra Soares
}

\author{
Universidade Federal Rural do Semi-Árido, Centro de Ciências Vegetais, Departamento de Ciências Agronômicas e \\ Florestais, Av. Francisco Mota, 572, Costa e Silva, CEP 59625-900, Mossoró, RN, Brazil
}

\author{
*Corresponding author: aurelio.barros@ufersa.edu.br
}

\begin{abstract}
Lettuce is a vegetable crop that requires a large supply of nutrients in a readily available form, within a short period of intense vegetative growth. The use of green manuring, with spontaneous species of the Caatinga biome, can quickly increase the organic matter content in the soil, providing nutrients for the crop. Therefore, the objective of this work was to evaluate the agronomic performance and economic profitability of lettuce fertilized with Calotropis procera in single crop under the semi-arid conditions of the state of Rio Grande do Norte, Brazil. The experimental design was a randomized complete block, with four treatments and five replicates. The treatments consisted of four amounts of $C$. procera biomass incorporated into the soil $\left(10,25,40\right.$, and $55 \mathrm{t}$ ha ${ }^{-1}$ of dry matter). The maximum agronomic efficiency of lettuce productivity was obtained for a yield of $18.16 \mathrm{t} \mathrm{ha}^{-1}$, with $40.29 \mathrm{t} \mathrm{ha}^{-1}$ of C. procera biomass added to the soil. The maximum economic efficiency of lettuce yield was achieved by the net income of AU\$3,006.50 (R\$7,546.31 ha $\left.{ }^{-1}\right)$, provided by the production of $17.65 \mathrm{t} \mathrm{ha}^{-1}$ of fresh mass, with $32.20 \mathrm{t} \mathrm{ha}^{-1}$ of $C$. procera biomass added to the soil. The use of $\mathrm{C}$. procera as a green manure presents agro-economic feasibility for lettuce cultivation in the semi-arid conditions of the Rio Grande do Norte state.
\end{abstract}

Keywords: Lactuca sativa, Calotropis procera, productive efficiency, green manure, organic manuring.

Introduction

Lettuce is one of the leafy vegetable crops that is widely exploited and consumed throughout Brazil (Batista et al., 2012). Its cultivation has limitations, mainly due to its sensitivity to the adverse conditions of temperature, humidity and rainfall (Gomes et al., 2005). In addition, the ideal soil for its cultivation is one of average texture, rich in organic matter, and with a good availability of nutrients. In order to obtain the highest productivity and profitability from its cultivation, an appropriate management of the factors contributing to its production, such as cultivar and fertilization, among others, was necessary.

Organic fertilization is an important factor in increasing the productivity of vegetable crops (Fontanétti et al., 2006). Organic fertilizers are not only useful for the nutrients they contain, but also for their beneficial effects on soil. Organic matter acts as an energy source for useful microorganisms in the soil, and its incorporation improves soil structure and aeration, its capability of storing moisture and regulating temperature, and increases its ability to exchange cations.

Like many other leafy vegetable crops, lettuce requires a large supply of readily available nutrients, within a short period of intense vegetative growth. The use of green manure, using spontaneous species of the Caatinga biome, can increase the soil organic matter content, improving nutrient availability to the crop and, thus, increasing productivity (Souza et al., 2015; Oliveira et al., 2015; Batista et al., 2016).

Among these spontaneous species are Merremia aegyptia L., Calotropis procera (Ait.) R.Br., and Senna uniflora L. Some studies have confirmed the agronomic efficiency of green manure containing these species in the cultivation of vegetable crops. Bezerra Neto et al. (2011), evaluating the agronomic performance of lettuce, as a function of different amounts and decomposition times of green $M$. aegyptia incorporated into the soil, concluded that the highest productivity of lettuce was obtained with the incorporation of $6.11 \mathrm{t} \mathrm{ha}^{-1}$ of $M$. aegyptia in the 20 days before transplanting the lettuce.

Góes et al. (2011), transplanting lettuce in soil fertilized with $M$. aegyptia, obtained higher lettuce productivity (15.33 t $\mathrm{ha}^{-1}$ ) with the incorporation in the soil of $6.68 \mathrm{tha}^{-1}$ of dry $M$. aegyptia in a decomposition time of 30 days before transplanting lettuce. 
On the other hand, Almeida et al. (2015), working with lettuce and arugula in an intercropped system, obtained a higher productivity of lettuce $\left(15.78 \mathrm{t} \mathrm{ha}^{-1}\right)$, a higher green mass yield of arugula $\left(4.30 \mathrm{tha}^{-1}\right)$, and an optimization of the agronomic performance for the association of lettuce and arugula with the incorporation of approximately 36.69, 37.96 and $36.93 \mathrm{t} \mathrm{ha}^{-1}$ of $C$. procera into the soil, respectively. In the autumn, in Serra Talhada (Pernambuco state, northeast Brazil), Souza et al. (2016) observed a maximum production of monocropped arugula when they incorporated $15.6 \mathrm{t} \mathrm{ha}^{-1}$ of $C$. procera 20 days before planting.

Linhares et al. (2010), sowing coriander fertilized with S. uniflora in cover in vase cultivation, observed higher productivity of this leafy vegetable ( $\left.11.5 \mathrm{~g} \mathrm{plot}^{-1}\right)$ at 28 days after its coverage.

Due to the lack of scientific information on lettuce fertilized with C. procera in a monoculture production system, the aim of this work was to evaluate the agronomic performance and economic profitability of this vegetable, fertilized with $C$. procera, under the semi-arid conditions of the state of Rio Grande do Norte, Brazil.

\section{Results and Discussion}

\section{Agronomic advantages}

From the results of the regression analysis of the evaluated agronomic characteristics of the lettuce, we observed a polynomial relationship between each characteristic and increasing amounts of green manure biomass incorporated into the soil (Fig.1). Thus, the height and diameter of the plants, number of leaves per plant, and productivity and dry mass of the lettuce shoots increased up to maximum values of 13.44 and $18.53 \mathrm{~cm}, 11.3$ leaves per plant, 18.11 and 0.95 $\mathrm{t} \mathrm{ha}^{-1}$, respectively, with the following amounts of $C$. procera biomass added: $36.83,40.85,39.70,40.29$ and $39.73 \mathrm{t} \mathrm{ha}^{-1}$, respectively, decreasing until the final biomass dosage of the applied manure (Fig. 1).

This polynomial behavior, and the optimization of each agronomic characteristic of the lettuce, can be attributed to the law of maximum, where the excess of a nutrient in the soil can cause toxic effects and/or decrease the effectiveness of other nutrients, thus reducing the values of the analyzed variables. Another justification that may be related to this behavior and optimization is adequate synchrony between the period of higher nutrient demand by the lettuce and the release of nutrients by the $C$. procera biomass.

According to Silva, Maia and Oliveira (2000), the study of organic matter dose on lettuce confirm that the susceptibility of the organic material to mineralization is essential to ensure that the stages of higher nutrient demand of the crop are synchronized with the release of the mineralized nutrients from the organic fertilizer.

Góes et al. (2011), studying the performance of lettuce fertilized by different quantities of dry hairy woodrose, obtained similar productive behavior to this study, in relation to the lettuce. On the other hand, Bezerra Neto et al. (2011), working with lettuce fertilized with green hairy woodrose, observed a productive performance similar to that of lettuce fertilized with $C$. procera incorporated into the soil.

\section{Economic advantages}

From the results of the regression analysis of the economic indices of the lettuce, as a function of the amounts of $C$. procera incorporated into the soil, a polynomial relationship between each economic index and the increasing amounts of this fertilizer can be observed (Fig. 2).

Gross income, net income, rate of return and net profit margin increased up to the maximum values of $R \$ 25.359,44$ $\mathrm{ha}^{-1}$ (AU\$10,103.36), R\$7.546,31 ha ${ }^{-1}$ (AU\$3,006.50), 1.44 per real invested and $30.18 \%$, respectively, from the following amounts of incorporated $C$. procera biomass: $40.29,32.20,30.82$ and $32.88 \mathrm{t} \mathrm{ha}^{-1}$, respectively, decreasing until the last amount of fertilizer was added (Fig. 2).

According to Beltrão et al. (1984), the net income better expressed the economic value than the gross income, because from this is deducted the costs of production. This index allows the producer to visualize the best technology to use in the lettuce production process, in terms of agroeconomic efficiency.

These results show that the net income expresses the advantage of using the amount of $32.20 \mathrm{t} \mathrm{ha}^{-1}$ of $C$. procera incorporated into the soil as a component in monetary terms, indicating that a quantity greater than this would become economically unviable, due to it placing a burden on the cropping system. Thus, we infer that this amount of $32.20 \mathrm{t} \mathrm{ha}^{-1}$ of $C$. procera provided a greater availability of nutrients to the plants, providing a higher productivity of the cultivated lettuce.

Linhares (2009), in evaluating the economic indicators of the productive performance of arugula as a function of the quantities and types of green manure incorporated into the soil, obtained higher income and monetary efficiency when the arugula was fertilized with $C$. procera in the amount 15.6 $\mathrm{t} \mathrm{ha}^{-1}$, with the following values: gross income $\mathrm{R} \$ 37,635.00$ $\mathrm{ha}^{-1} \quad(\mathrm{AU} \$ 14,994,02)$; net income $\mathrm{R} \$ 34,189.00 \mathrm{ha}^{-1}$ (AU\$13,621.11); rate of return 10.92 per real invested; and a net profit margin of $90.84 \%$.

\section{Materials and Methods}

\section{Site description}

The study was conducted at the 'Rafael Fernandes' experimental farm of the Department of Plant Sciences, Universidade Federal Rural do Semi-Árido (UFERSA), Mossoró-RN (503'37"S, 37²3'50"W Gr), in a Eutrophic RedYellow Argisol, from July to September, 2012.

Before the experiment installation, soil samples from the experimental area, from $0-20 \mathrm{~cm}$ depth, were collected and sent for chemical analysis in the Laboratory of Analysis of Water, Soils and Plants of the Environmental Sciences Department of UFERSA. The results were: $\mathrm{pH}=6.80 ; \mathrm{P}=6.30$ $\mathrm{mg} \mathrm{dm}{ }^{-3} ; \mathrm{K}=85.20 \mathrm{mg} \mathrm{dm}^{-3} ; \mathrm{Ca}=2.01 \mathrm{cmol}_{\mathrm{c}} \mathrm{dm}^{-3} ; \mathrm{Mg}=1.09$ $\mathrm{cmol}_{\mathrm{c}} \mathrm{dm}^{-3} ; \mathrm{Na}=35.90 \mathrm{mg} \mathrm{dm}{ }^{-3} ;$ sum of bases $=3.47 \mathrm{cmol}_{\mathrm{c}}$ $\mathrm{dm}^{-3}$ and base saturation $=91 \%$. For this analysis, the soil 

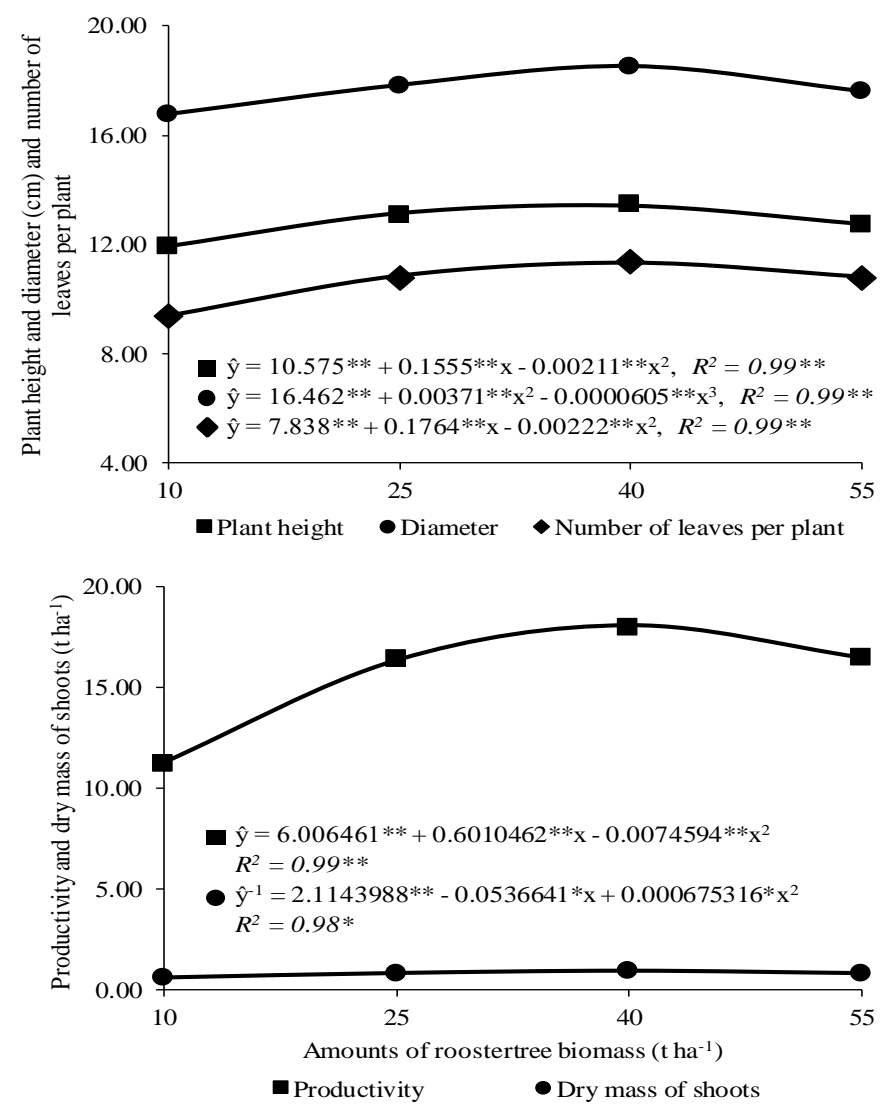

Fig 1. Plant height and diameter, number of leaves per plant, productivity and dry mass of shoots of lettuce with different amounts of roostertree biomass incorporated into the soil.
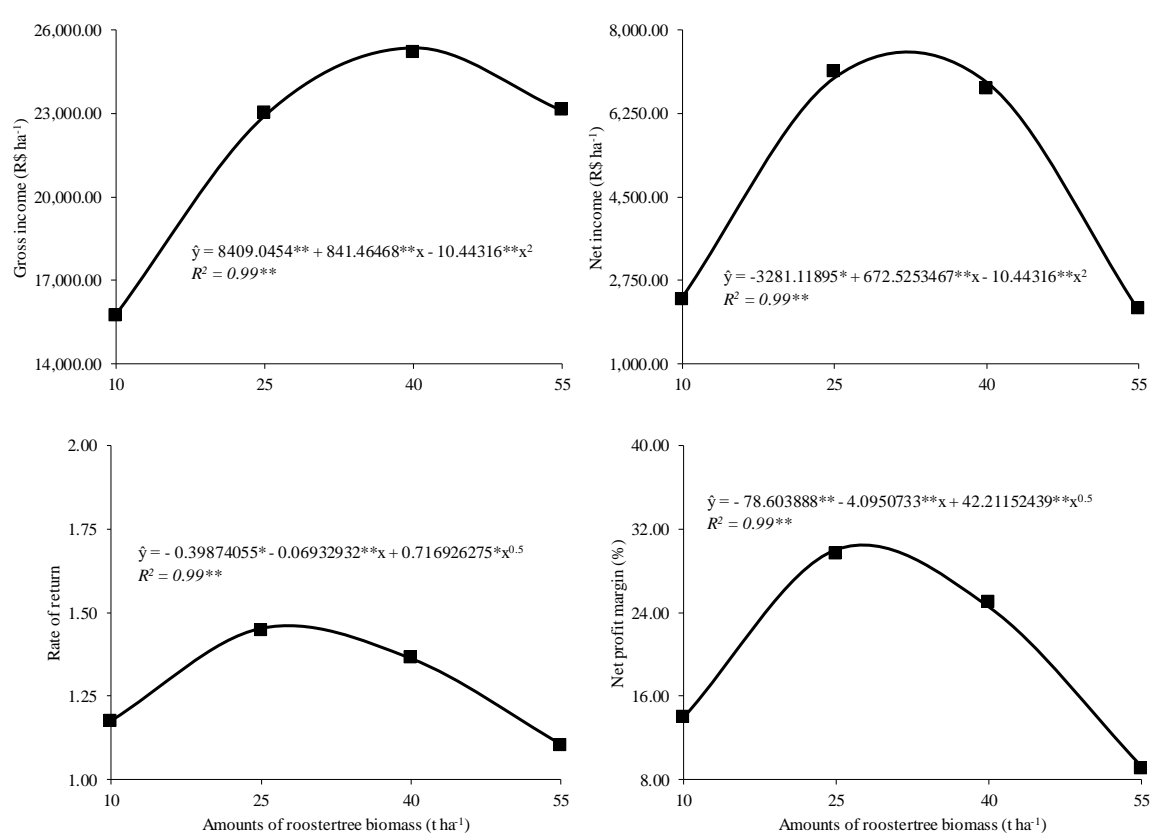

Fig 2. Gross income, net income, rate of return and net profit margin of lettuce with different amounts of roostertree biomass incorporated into the soil. 
chemical analysis methodology of EMBRAPA was used (EMBRAPA, 2009).

\section{Experimental procedure}

The experimental design was a randomized complete block, with four treatments and five replicates. The treatments consisted of four quantities of $C$. procera incorporated into the soil $\left(10,25,40\right.$ and $55 \mathrm{t} \mathrm{ha}^{-1}$ on dry base). These doses of green manure used in the lettuce fertilization were chosen, based on the methodology used by Oliveira (2014) when studying the cultivation of this broad leafy vegetable in association with arugula and carrot in polyculture, at the same place in which this study was conducted. Each plot had a total area of $1.44 \mathrm{~m}^{2}(1.2 \mathrm{~m} \times 1.2 \mathrm{~m})$, containing 36 lettuce plants spaced $0.2 \mathrm{~m} \times 0.2 \mathrm{~m}$ apart. The harvest area of each plot was $0.8 \mathrm{~m}^{2}(1.0 \mathrm{~m} \times 0.8 \mathrm{~m})$ containing 16 lettuce plants.

\section{Management and cropping system}

The preparation of the beds was done manually with a hoe. The incorporation of the $C$. procera in the different amounts in each plot was done with a hoe to the depth of $0-20 \mathrm{~cm}$. A solarization with 30-micron clear plastic was carried out for 45 days, in order to reduce the soil phytopathogen population.

The green manure was collected from native vegetation sites in the municipalities of Mossoró and Tibau, in Rio Grande do Norte state, prior to flowering. It was then crushed in a conventional forage machine to yield fragments of $2-3 \mathrm{~cm}$ that were dried until hay conditions were reached $(10 \%$ humidity).

Five simple samples of this material were collected and transformed into a composite sample, which was sent to the Soil, Water and Plant Laboratory of the UFERSA, Mossoró$\mathrm{RN}$, to be analyzed. The results obtained were as follows: $\mathrm{N}=$ $44.20 \mathrm{~g} \mathrm{~kg}^{-1} ; \mathrm{P}=1.30 \mathrm{~g} \mathrm{~kg}^{-1} ; \mathrm{K}=42.13 \mathrm{~g} \mathrm{~kg}^{-1} ; \mathrm{Ca}=8.43 \mathrm{~g} \mathrm{~kg}^{-1}$; $\mathrm{Mg}=2.57 \mathrm{~g} \mathrm{~kg}^{-1} ; \mathrm{Fe}=342.33 \mathrm{mg} \mathrm{kg}^{-1} ; \mathrm{Zn}=30.67 \mathrm{mg} \mathrm{kg}^{-1} ; \mathrm{Cu}$ $=8.0 \mathrm{mg} \mathrm{kg}^{-1} ; \mathrm{Mn}=213 \mathrm{mg} \mathrm{kg}^{-1} ;$ and a $\mathrm{C} / \mathrm{N}$ ratio of $16 / 1$.

The cultivar of planted lettuce was 'Tainá', adapted for cultivation in the northeastern region. The lettuce was seeded in polystyrene trays with 128 cells, containing a commercial substrate of expanded vermiculite type $B$, with the following chemical composition: $\mathrm{SiO}_{2}=45.1 \%$; $\mathrm{MgO}=$ 23.6\%; $\mathrm{Al}_{2} \mathrm{O}_{3}=10.2 \% ; \mathrm{Fe}_{2} \mathrm{O}_{3}=5.8 \% ; \mathrm{K}_{2} \mathrm{O}=0.5 \% ; \mathrm{Na}_{2} \mathrm{O}=$ $0.1 \% ; \mathrm{CaO}=3.60 \% ; \mathrm{TiO}_{2}=0.7 \% ; \mathrm{BaO}=0.2 \%$; and $\mathrm{H}_{2} \mathrm{O}$ (total) $=10.2 \%$ (Hindman, 1994).

Three seeds were sown in each cell, and after 10 days of emergence, thinning was performed, leaving one seedling per cell. The lettuce seedlings were produced by hydroponics in a nursery covered with white nylon mesh. The lettuce seedlings were transplanted to each experimental plot on August 21, 2012, 26 days after sowing (July 26, 2012).

Irrigation of the field experiment was performed by microsprinkler, with daily irrigations divided into two applications (morning and afternoon), providing a mean water sheet of 8 $\mathrm{mm} \mathrm{d}^{-1}$. Manual weeding was performed whenever necessary. No additional fertilization was performed.

The lettuce harvest was performed at 27 days after transplanting, when the plants reached maximum vegetative development. At the time of harvest, the plant stems were cut close to the soil, and the following characteristics were evaluated: plant height and diameter; number of leaves per plant; and dry and fresh matter mass of shoots (productivity).

\section{Measured characteristics}

All measurements below were made on a sample of five plants, taken randomly from the harvest plot.

The height of the plants was measured by graduated ruler, from soil level to the top of the highest leaf, and expressed in $\mathrm{cm}$. The diameter of the plants was evaluated by measuring the distance between the opposing edges of the leaf disc, these measurements being made at the time of harvest, by graduated ruler, estimating the mean, and expressing the diameter in $\mathrm{cm}$. The number of leaves per plant was obtained by counting the basal leaves to the last open leaf with $5 \mathrm{~cm}$ of length.

The dry mass of the shoots was obtained by first drying these in a forced air circulation oven at $65^{\circ} \mathrm{C}$, until a constant mass was obtained, and then weighing and expressing this mass in $\mathrm{t} \mathrm{ha}^{-1}$. The productivity was determined from the fresh mass of the shoots of the plants of the harvest plot and expressed in $\mathrm{tha}^{-1}$.

The gross income (GI) from the tested treatments was obtained through the value of production per hectare (R\$ $\left.\mathrm{ha}^{-1}\right)$, at a price $\left(\mathrm{R} \$ 1.40 \mathrm{~kg}^{-1}\right)$ paid to the producer at market in the region in December 2012. The current exchange rate of the AU\$ was $\$ 1=R \$ 2.51$, in September 2017.

The net income (NI) was calculated by the following expression: $N I=G I-T C$, where TC (total costs of production) is the sum of all expenses (input and labor) for each treatment. This is expressed in $R \$ h^{-1}$.

The rate of return (RR) was obtained by the expression $R R=G I / T C$. The net profit margin (NPM) was obtained as the ratio of $\mathrm{NI}$ to $\mathrm{Gl}$, expressed as a percentage.

\section{Statistical analysis}

A univariate analysis of variance was used to evaluate the effects of the treatments, using the software Sisvar (Ferreira, 2011). A response curve adjustment procedure for each characteristic, as a function of the amount of $C$. procera, was performed using Table Curve software (Scientific, 1991).

\section{Conclusion}

A maximum agronomic efficiency of the productivity of lettuce was obtained for the yield of $18.16 \mathrm{t} \mathrm{ha}^{-1}$, with 40.29 $\mathrm{t} \mathrm{ha}^{-1}$ of $C$. procera biomass added to the soil. The maximum economic efficiency of the productivity of lettuce was reached for the net income of $A U \$ 3,006.50$ (R\$7,546.31 ha $\left.{ }^{1}\right)$, provided by the production of $17.65 \mathrm{t} \mathrm{ha}^{-1}$ of fresh mass, with $32.20 \mathrm{t} \mathrm{ha}^{-1}$ of $C$. procera biomass incorporated into the soil. The use of $C$. procera as a green manure presents agroeconomic feasibility for the cultivation of lettuce under the semi-arid conditions of Rio Grande do Norte. 


\section{Acknowledgements}

Special thanks are due to the Coordenação de Aperfeiçoamento de Pessoal de Nível Superior for their financial support of this work, and to the research group at the Crop Science Department of the Universidade Federal Rural do Semi-Árido, which develops technologies for growing vegetable crops on family farms.

\section{References}

Almeida AES, Bezerra Neto F, Costa LR, Silva ML, Lima JSS, Barros Júnior AP (2015) Eficiência agronômica do consórcio alface-rúcula fertilizado com flor-de-seda. Rev Caatinga. 28:79-85.

Batista MAB, Vieira LA, Souza JP, Freitas JDB, Bezerra Neto F (2012) Efeito de diferentes fontes de adubação sobre a produção de alface no município de Iguatu-CE. Rev Caatinga. 25:8-11.

Batista TMV, Bezerra Neto F, Silva IN, Silva ML, Oliveira EQ, Barros Júnior AP (2016) Agronomic efficiency of the intercropping of arugula with carrot under different population combinations. Rev Caatinga. 29:76-84

Beltrão NEM, Nóbrega LB, Azevedo DMP, Vieira DJ (1984) Comparação entre indicadores agroeconômicos de avaliação de agroecossistemas consorciados e solteiros envolvendo algodão upland e feijão "caupi". CNPA, Campina Grande (Boletim de Pesquisa, 15).

Bezerra Neto F, Góes SB, Sá JR, Linhares PCF, Góes GB, Moreira JN (2011) Desempenho agronômico da alface em diferentes quantidades e tempos de decomposição de jitirana verde. Rev Bras Cienc Agrar. 6:236-242.

EMBRAPA (2009) Manual de análises químicas de solos, plantas e fertilizantes. 2a edição revisada e ampliada. EMBRAPA, Brasília.

Ferreira DF (2011) Sisvar: a computer statistical analysis system. Cienc Agrotec. 35:1039-1042.

Fontanétti A, Carvalho GJ, Gomes LAA, Almeida K, Moraes SRG, Teixeira CM (2006) Adubação verde na produção orgânica de alface americana e repolho. Hortic Bras. 24:146-150.

Góes SB, Bezerra Neto F, Linhares PCF, Góes GB, Moreira JN (2011) Productive performance of lettuce at different amounts and times of decomposition of dry scarlet starglory. Rev Cienc Agron. 42:1036-1042.

Gomes TM, Modolo VA, Botrel TA, Oliveira RF (2005) Aplicação de $\mathrm{CO}_{2}$ via água de irrigação na cultura da alface. Hortic Bras. 23:316-319.

Hindman JR (1994) Vermiculite. In: Carr DD (ed). Industrial minerals and rocks. Society of Mining, Metallurgy, and Exploration, Littleton, Colorado.

Linhares PCF (2009) Vegetação espontânea como adubo verde no desempenho agroeconômico de hortaliças folhosas. Mossoró: UFERSA, 2009. 109p. Dissertation (Doctorate in Plant Science) - Universidade Federal Rural do Semi-Árido (UFERSA), Mossoró, RN.

Linhares PCF, Fernandes, YTD, Silva ML, Pereira MFS, Santos AP (2010) Decomposição do mata-pasto em cobertura no desempenho agronômico do coentro. Rev Verde. 5:163171

Oliveira LAA (2014) Bicultivo de rúcula e alface em policultivo com cenoura sob quantidades de flor-de-seda e proporções de densidades populacionais. 2014. 108p. Dissertation (Doctorate in Plant Science) - Universidade Federal Rural do Semi-Árido (UFERSA), Mossoró, RN.

Oliveira LAA, Bezerra Neto F, Silva ML, Oliveira OFN, Lima JSS (2015) Viabilidade agronômica de policultivos de rúcula/cenoura/alface sob quantidades de flor-de-seda e densidades populacionais. Rev Caatinga. 28:116-126.

Scientific J (1991)Table curve: curve fitting software. Jandel Scientific, Corte Madera.

Silva FN, Maia SSS, Oliveira M (2000) Doses de matéria orgânica na produtividade da cultura da alface em solo Eutrófico da Região de Mossoró, RN. Hortic Bras. 18:776777.

Souza EGF, Barro Júnior AP, Bezerra Neto F, Silveira LM, Leal YH, Alves MJG (2015) Rentabilidade da rúcula fertilizada com biomassa de flor-de-seda em função da época de cultivo. Rev Caatinga. 28:65-77.

Souza EGF, Santana FMS, Martins BNM, Santos MG, Cerqueira Júnior EP, Barro Júnior $A P$, Silveira $L M$, Bezerra Neto F, Lins HA, Albuquerque JRT (2016) Agronomic response of arugula to green fertilization with rooster tree during two culture times. African J Agr Res. 11:4931-4938. 